\title{
Intestinal malabsorption in Strongyloides stercoralis infestation
}

\author{
P. F. MILNER, R. A. IRVINE, C. J. BARTON, G. BRAS, AND R. RICHARDS \\ From the Departments of Pathology and Medicine, University of the West Indies, \\ Kingston, Jamaica
}

EDITORIAL SYNOPSIS The number of conditions which can result in intestinal malabsorption increases steadily. The one described by the authors in this paper follows infestation with Strongyloides stercoralis which is widespread in the tropics. Features suggesting the diagnosis in a patient with malabsorption are, according to the authors, persistent vomiting due to duodenal involvement and characteristic radiographs of the duodenum. The diagnosis is proven when the duodenal mucosa is examined and the lesion can be treated, when the symptoms will disappear.

The disease states that may be associated with intestinal malabsorption are numerous, and a recent review lists almost 40 of these (Jeffries, Weser, and Sleisenger, 1964). As the majority of publications on this subject originate in temperate countries, it is not surprising that there are few references to malabsorption resulting from parasitic infestation of the bowel. Steatorrhoea has, however, been described in giardiasis (Amini, 1963; Zamcheck, Hoskins, Winawer, Broitman, and Gottlieb, 1963) and in hookworm disease (Sheehy, Meroney, Cox, and Soler, 1962; Salem and Truelove, 1964).

Infestation with the helminth Strongyloides stercoralis is widespread in tropical countries and, although in the majority of instances the infestation is asymptomatic, serious disease and even death may ensue (Bras, Richards, Irvine, Milner, and Ragbeer, 1964). Intestinal malabsorption resulting from the disease is rare (Stemmermann and Nakasone, 1960; Alcorn and Kotcher, 1961).

The clinical picture of severe malnutrition with a bizarre duodenal lesion seen on radiographs and larvae of Strongyloides in duodenal biopsies as well as in the stools has not been previously reported.

The greatly depressed absorption of iron salts demonstrated in these cases is also of interest. In the four cases reported here there was incontrovertible evidence of intestinal malabsorption resulting from strongyloidiasis.

\section{LABORATORY INVESTIGATIONS}

SERUM IRON AND IRON-BINDING CAPACITY These were estimated by the method of Beale, Bostrom, and Taylor (1961, 1962).
IRON ABSORPTION TESTS The patients were fasting when two tablets (400 mg.) of ferrous sulphate $(130 \mathrm{mg}$. of elemental iron) were given and blood specimens taken for serum iron and iron-binding capacity at hourly intervals for four hours.

XYLOSE AND FOLIC ACID ABSORPTION TESTS These tests were done according to the method of Chanarin and Bennett (1962) using $0.4 \mathrm{~g}$. of xylose and $40 \mu \mathrm{g}$. of folic acid per kilogram body weight in a single dose. Xylose was estimated in urine and serum by the method of Roe and Rice (1948) and folic acid was measured by microbiological assay using Streptococcus faecalis (Chanarin, Anderson, and Mollin, 1958).

DUODENAL AND JEJUNAL BIOPSIES Biopsies were taken under fluoroscopic control using a Crosby capsule (Crosby and Kugler, 1957). Specimens were examined under a dissecting microscope before fixation as well as in stained histological sections cut vertically.

\section{CASE REPORTS}

CASE 1 A 28-year-old Jamaican housewife was admitted to the University College Hospital of the West Indies in March 1964. She gave a history of vomiting, diarrhoea, and weight loss for three months. In the three weeks preceding admission she had experienced lower abdominal pain, fever, ankle oedema, and skin rash. She presented the classical picture of kwashiorkor in the adult; there was dehydration and cachexia, with generalized oedema and ascites; her body was covered with a scaly, purpuric rash associated with dyspigmentation and desquamation of the groins, perineum, and limbs (Fig. 1). The liver was enlarged and smooth but there was no splenomegaly.

It is unusual to see severe protein malnutrition in adults in Jamaica without there being some predisposing underlying disease. Detailed investigations were therefore 


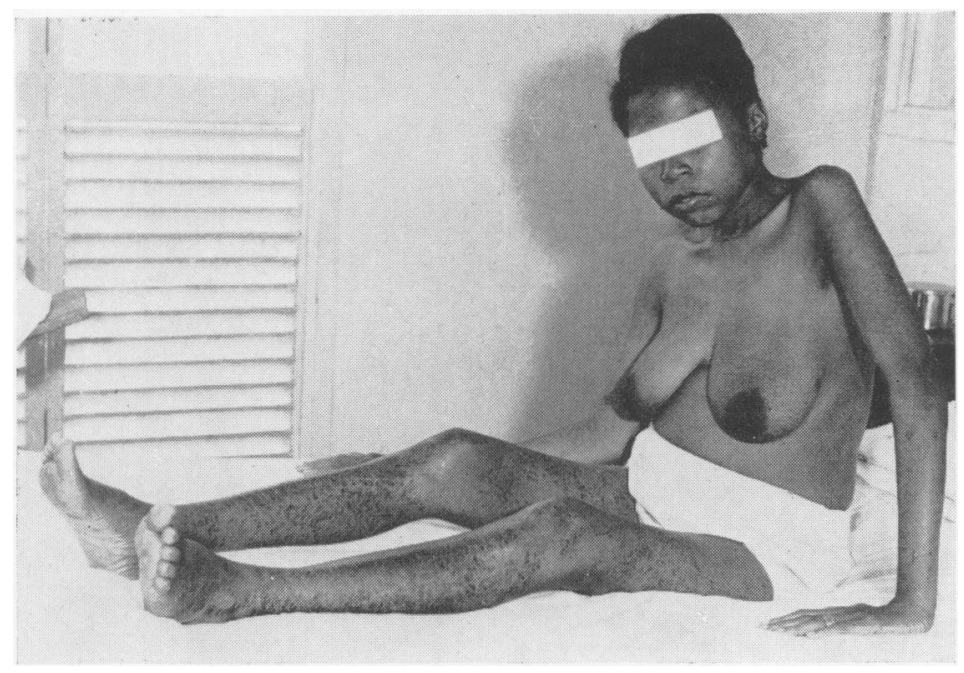

FIG. 1. Photograph of case 1 showing the typical appearance of adult kwashiorkor with oedema, ascites, and dyspigmentation.

carried out to confirm the clinical impression of a malabsorption syndrome.

Investigations and clinical course The patient was mildly anaemic (haemoglobin $10.4 \mathrm{~g}$. per $100 \mathrm{ml}$.; mean corpuscular haemoglobin concentration (M.C.H.C.) $30 \%$ ). The leucocyte count was 10,400 per c.mm. Liver function tests were abnormal in some parameters; serum albumin $2.0 \mathrm{~g}$. per $100 \mathrm{ml}$., falling later on to $1.6 \mathrm{~g}$. per $100 \mathrm{ml}$., and alkaline phosphatase 19 K.A. units. Total serum iron-binding capacity (TIBC) was also reduced $(175 \mu \mathrm{g}$. per $100 \mathrm{ml}$.) with a serum iron level of $83 \mu \mathrm{g}$. per $100 \mathrm{ml}$, and $42 \%$ saturation. The prothrombin time was 26 seconds (normal 12 seconds).

A barium meal showed dilatation of the first three parts of the duodenum with oedema of the mucosa. The bolus was delayed in the third part, close to the mid-line, and the cineradiographic studies demonstrated abnormal motility of the proximal part in the duodenal loop. A peroral biopsy from the duodenum showed flattening of the villi, heavy infiltration with inflammatory cells, and rhabditiform larvae of $S$. Stercoralis buried in the mucosa. A further biopsy from the proximal jejunum showed a similar picture. Absorption of xylose and folic acid was poor. Only $8 \%$ of the xylose dose was excreted in the urine (normal 13-31\%), while the serum concentration at one and two hours was $5.7 \mathrm{mg}$. per $100 \mathrm{ml}$., and $21 \cdot 3$ mg. per $100 \mathrm{ml}$., respectively (normal $32-67 \mathrm{mg}$. per
$100 \mathrm{ml}$.). Of the folic acid dose, $6.5 \%$ was excreted (normal 12-44\%) and serum levels at one and two hours were $13.0 \mu \mathrm{mg}$. per $100 \mathrm{ml}$. and $22.0 \mu \mathrm{mg}$. per $100 \mathrm{ml}$, respectively (normal 51-142 $\mu \mathrm{mg}$. per $100 \mathrm{ml}$.). The serum vitamin $B_{12}$ concentration at this time was 1,950 $\mu \mu \mathrm{g}$. per ml., this high value being compatible with impaired liver function. There was hardly any rise in the serum iron level four hours after the ingestion of ferrous sulphate.

The patient was treated with parenteral fluids, highprotein oral feeds, kaolin for diarrhoea, and dithiazanine (Telmid) for the helminthic infestation. Potassium depletion with asthenia, ileus, and hypotension was a serious problem as her stools volume at this time was 3 litres a day. She remained critically ill for over three weeks. After this, $S$. stercoralis larvae disappeared from the stools, the diarrhoea abated, and she began to recover. Giardia lamblia was then found in the stools but it disappeared on treatment with mepacrine.

Before she was discharged, after a stay of 11 weeks, all investigations were repeated. The barium meal was now completely normal, and a biopsy of the duodenum showed normal villi with no evidence of parasites. Haemoglobin was 12.5 g. per $100 \mathrm{ml}$., and M.C.H.C. $32 \%$. The serum albumin was $4.9 \mathrm{~g}$. per $100 \mathrm{ml}$, , and the T.I.B.C. had risen to $357 \mu \mathrm{g}$. per $100 \mathrm{ml}$. The response to an iron absorption test was a serum iron level of $210 \mu \mathrm{g}$. per

TABLE I

RESULTS OF XYLOSE AND FOLIC ACID ABSORPTION TESTS BEFORE AND AFTER TREATMENT IN CASE 1

Xylose Absorption

\begin{tabular}{|c|c|c|c|c|c|c|}
\hline & \multicolumn{3}{|c|}{ Xylose Absorption } & \multicolumn{3}{|c|}{ Folic Acid Absorption } \\
\hline & Normal & $\begin{array}{l}\text { Before } \\
\text { Treatment }\end{array}$ & $\begin{array}{l}\text { After } \\
\text { Treatment }\end{array}$ & Normal & $\begin{array}{l}\text { Before } \\
\text { Treatment }\end{array}$ & $\begin{array}{l}\text { After } \\
\text { Treatment }\end{array}$ \\
\hline $\begin{array}{l}\text { Urinary excretion (\%) of dose } \\
\text { Peak serum level at one or two }\end{array}$ & $\begin{array}{l}13-31 \\
32-67(\mathrm{mg} . / \%)\end{array}$ & $\begin{array}{l}8 \cdot 1 \\
21 \cdot 3 \text { (mg./\%) }\end{array}$ & $\begin{array}{l}11.6 \\
44.0(\mathrm{mg} . / \%)\end{array}$ & $\begin{array}{l}12-44 \\
51-142 \text { (umg. } / \%)\end{array}$ & 22.0 ( 1 mg. $1 \%$ ) & $\begin{array}{l}22.4 \\
53.0 \\
(\mu \mathrm{mg} . / \%)\end{array}$ \\
\hline
\end{tabular}

hr. 


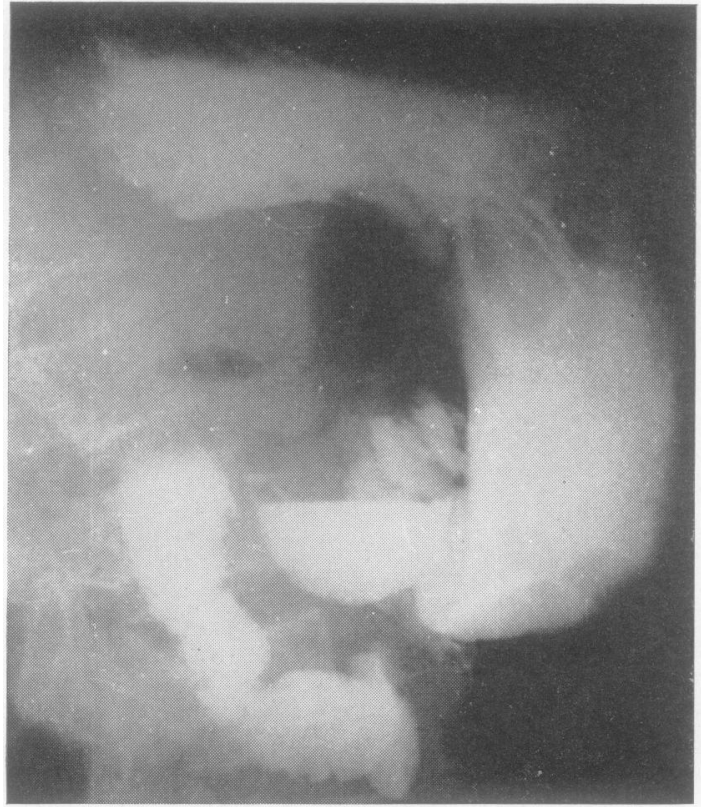

FIG. $2 \mathrm{a}$.

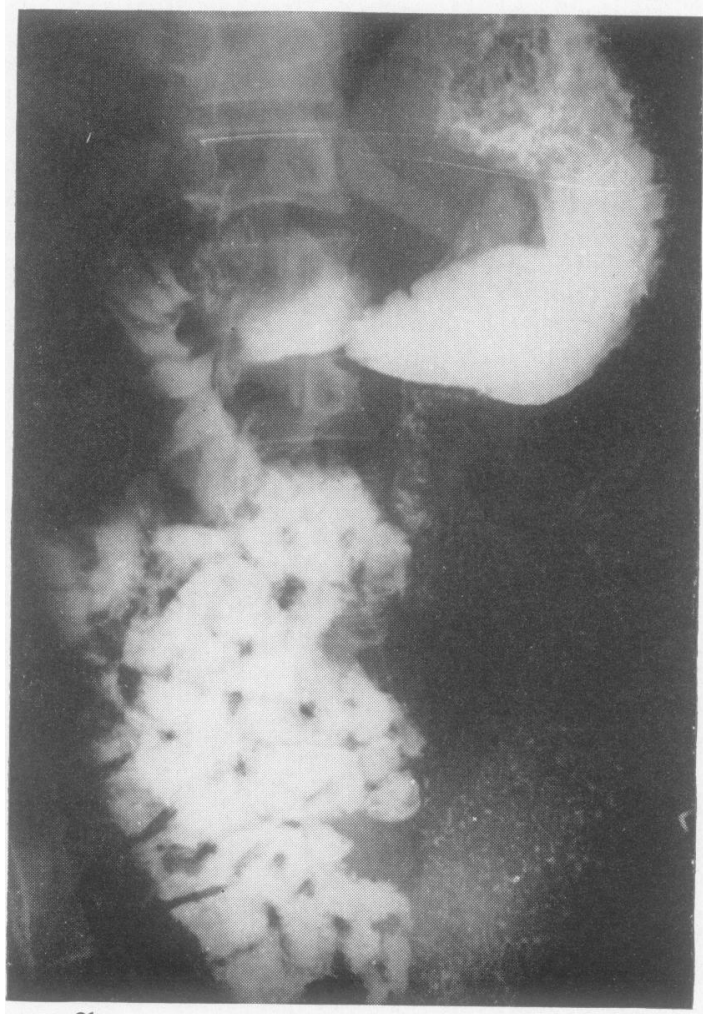

FIG. $2 b$

FIG. 2. Barium meal examination in case 2 showing a duodenal dilatation and ileus (above) and (below) same patient after treatment showing substantial improvement.

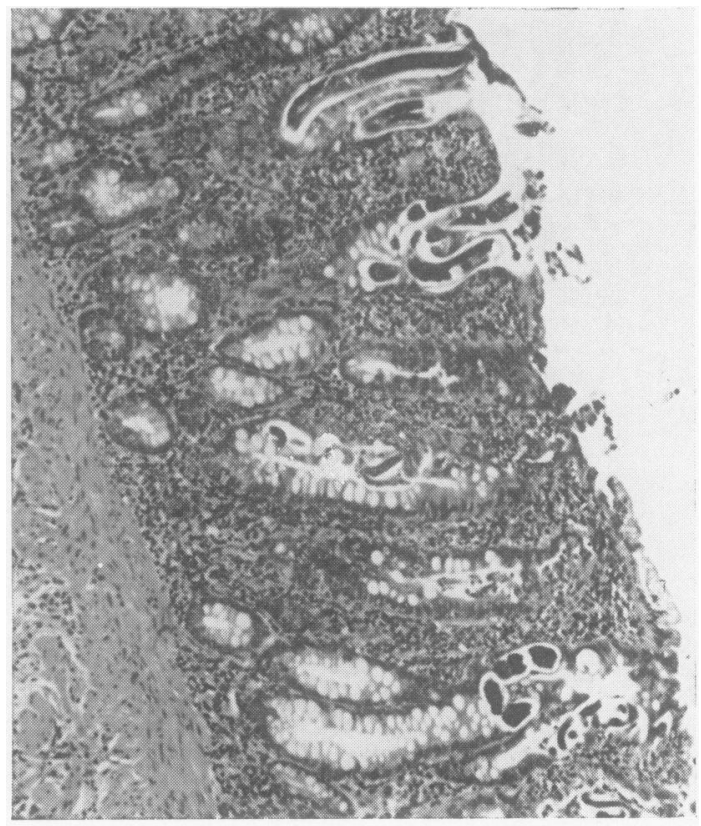

FIG. 3a.

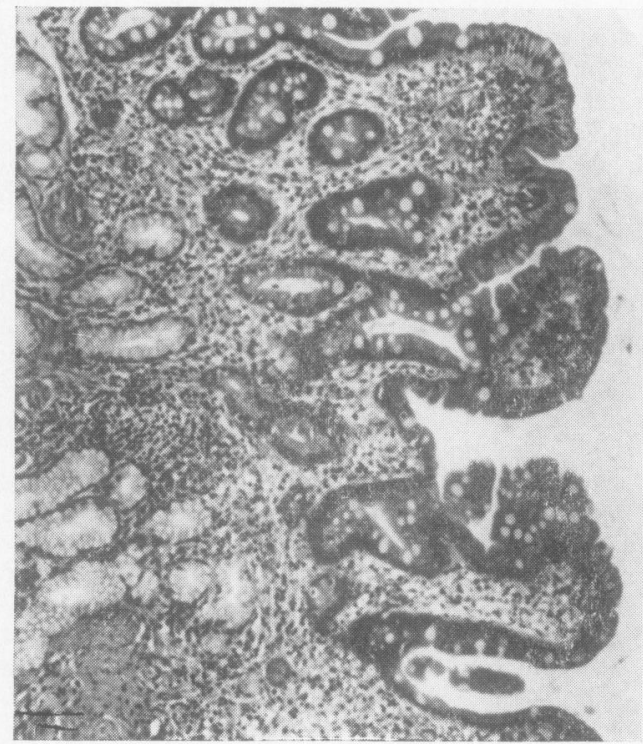

FIG. $3 b$.

FIG. 3a. Biopsy specimen of the duodenal mucosa in case 2 before treatment showing flattening of the villi, infiltration with inflammatory cells, and worms and ova of S. stercoralis in the crypts, and (Fig. $3 b$ ) after treatment with diathiazinine. The inflammation has almost completely disappeared, there are no $\mathbf{S}$. stercoralis, and the villi are reforming. 
$100 \mathrm{ml}$. at four hours (Fig. 5). Table I shows the improvement in xylose and folic acid absorption.

She had gained $4 \mathrm{lb}$. in weight, which was significant considering the loss of oedema and ascites.

CASE 2 A 17-year-old boy was first admitted to hospital in October 1963. He gave a history of epigastric pain and vomiting for eight weeks with weight loss for the preceding six months. Two months before admission he had reported to hospital with the typical picture of pyloric stenosis: vomiting, dehydration, visible peristalsis in the stomach, and weight loss. At that time he refused admission and apparently recovered spontaneously.

On admission he was not malnourished and there was no diarrhoea. S. stercoralis larvae were found in several stool specimens. A barium meal examination showed delay in the third part of the duodenum, with an altered mucosal pattern, areas of dilatation, and abnormal motility. The appearance was similar to that seen in case 1 . Radiographs taken before and after treatment are shown in Figure 2.

The haemoglobin level was $9 \cdot 6$ g. per $100 \mathrm{ml}$., M.C.H.C. $30 \%$, and white cell count 11,600 per c.mm., with $33 \%$ eosinophils. The serum albumin level was $4 \cdot 1 \mathrm{~g}$. per $100 \mathrm{ml}$., the serum T.I.B.C. was $387 \mu \mathrm{g}$. per $100 \mathrm{ml}$. with a serum iron level of $44 \mu \mathrm{g}$. per $100 \mathrm{ml}$, and saturation $11 \%$. Liver function tests were unremarkable

Peroral biopsy of the duodenum showed flattened villi, inflammatory infiltrate, and $S$. stercoralis worms. and ova in the crypts. Among the worms a pregnant female and rhabditiform larvae were seen (Fig. 3).

Xylose and folic acid absorption was within normal limits but an iron absorption test showed a flat curve despite a normal transferrin level. The significance of this flat iron absorption curve is better appreciated when compared with the result of a repeat test performed after treatment and recovery (Fig. 5).

The patient remained in hospital for six weeks and was treated with dithiazanine. On discharge he had gained $16 \mathrm{lb}$. in weight and the stools were free of $S$. stercoralis larvae. He has since remained symptom free.

CASE 3 A 13-year-old boy was first seen in May 1963. At that time he complained of vomiting and swollen legs for four weeks, followed by diarrhoea for three weeks. In addition he had had a generalized pruritic rash for at least one year. He was covered with an infected papular rash; there was oedema of the eyelids and swelling of the legs up to the knees. The tongue was red, smooth and moist, and enlarged lymph nodes were palpable in the neck, axillae, and groins. He was passing watery stools up to six times a day, containing $S$. stercoralis larvae.

His haemoglobin level was $9 \cdot 0$ g. per $100 \mathrm{ml}$., M.C.H.C. $30 \%$, and bone marrow examination showed normoblastic erythropoiesis without convincing evidence of iron deficiericy. The serum iron level, however, was $34 \mu \mathrm{g}$. per $100 \mathrm{ml}$., with an unsaturated iron-binding capacity of only $66 \mu \mathrm{g}$. per $100 \mathrm{ml}$., T.I.B.C. $100 \mu \mathrm{g}$. per $100 \mathrm{ml}$., saturation $34 \%$. The serum albumin level was $1.0 \mathrm{~g}$. per $100 \mathrm{ml}$. A glucose tolerance test showed a 'diabetic' curve with a fasting sugar of $105 \mathrm{mg}$. per $100 \mathrm{ml}$., and

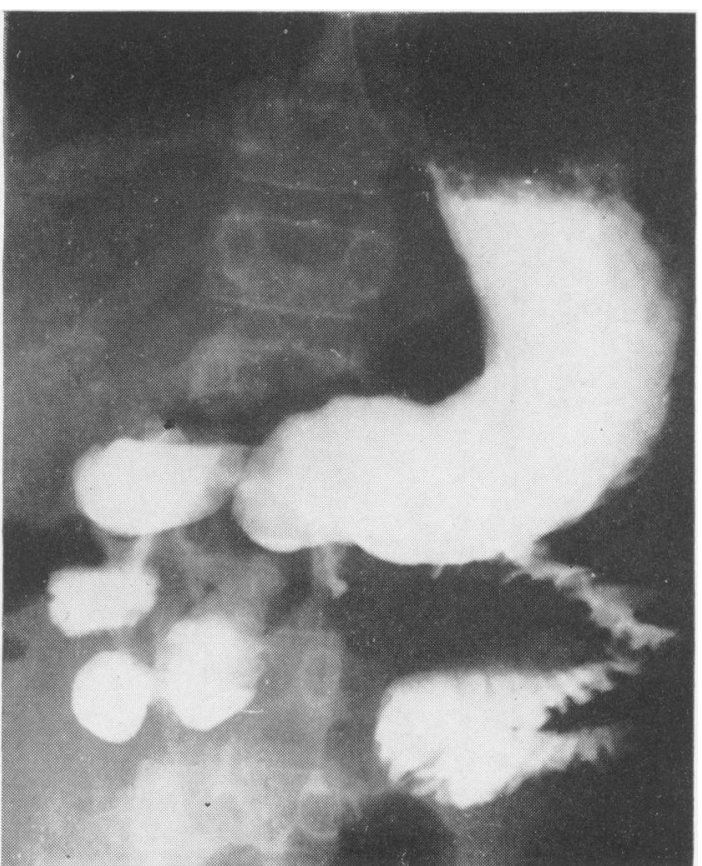

FIG. 4. Barium meal examination in case 3 showing similar appearance to case 2 with dilatation of duodenum and duodenal ileus.

two-hour and two and a half hour levels of 190 and 215 mg. per $100 \mathrm{ml}$., respectively. This presumably reflected pre-existing starvation due to vomiting. He had steatorrhoea, excreting 24 to $30 \mathrm{~g}$. fat daily, on a ward diet of between 50 and $75 \mathrm{~g}$. of fat a day. Barium examination of the duodenum showed dilatation of the proximal part of the loop with an obstructive lesion in the third part and abnormal motility. Follow-through examination of the small bowel showed a malabsorption pattern (Fig. 4).

He was treated with dithiazanine and the malnutrition was corrected. The reticulocyte count reached $11.5 \%$ on iron therapy and the haemoglobin rose to $12 \cdot 7 \mathrm{~g}$. per $100 \mathrm{ml}$. Serum iron level was now $145 \mu \mathrm{g}$. per $100 \mathrm{ml}$., T.I.B.C. $345 \mu \mathrm{g}$. per $100 \mathrm{ml}$. A glucose tolerance curve was normal. He was discharged after seven weeks, having gained $8 \mathrm{lb}$. in weight.

Some 10 months later he was readmitted because of abdominal pain and vomiting of three week's duration. Strongyloides stercoralis larvae were again found in the stools, but he was not malnourished and only mildly anaemic. Barium meal examination, however, showed the dilatation and oedema of the proximal duodenal loop to be more marked than at the previous admission. The abnormal motility and obstruction were still apparent. An attempt at peroral biopsy failed to provide a mucosal specimen but the duodenal aspirate teemed with larvae identified as Strongyloides stercoralis. Xylose and folic acid absorption tests were within normal limits but the iron absorption curve was flat (Fig. 5). 

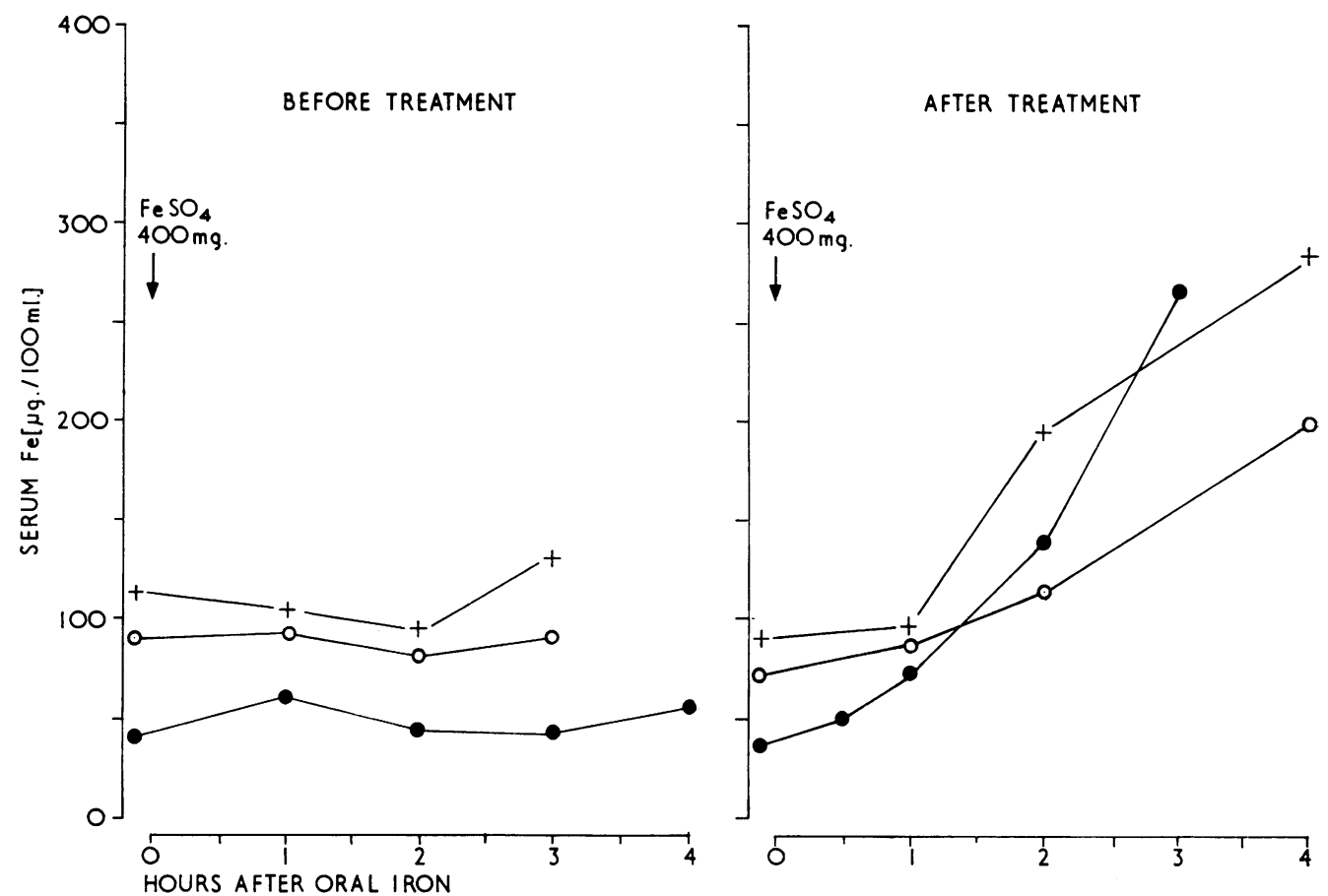

FIG. 2. Iron absorption test for duodenal function (case $1 \bigcirc-\bigcirc$, case 2, , case 3, +- +). Serum iron response after ingestion of $400 \mathrm{mg}$. of ferrous sulphate in the fasting subject, on admission and after the strongyloides infestation had been treated.

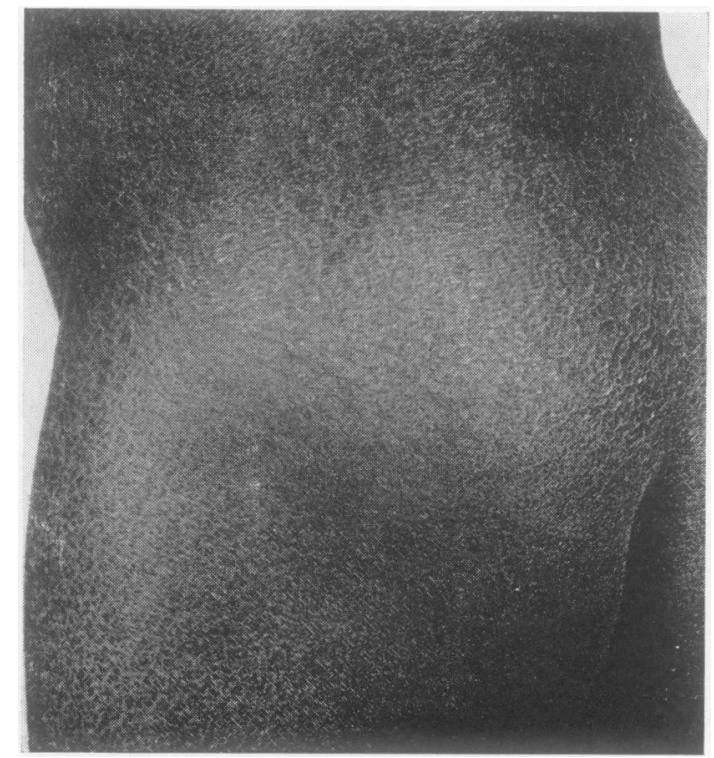

FIG. 6. Photograph showing scaly dermatosis typical of protein malnutrition.
After three weeks' treatment with dithiazanine Strongyloides larvae were still present in the stools and were found again, six weeks later, in spite of further treatment. By this time, however, he looked quite well, was not malnourished, and had a haemoglobin level of $11 \cdot 3 \mathrm{~g}$. per $100 \mathrm{ml}$, M.C.H.C. $33 \%$, and a serum albumin level of $3.9 \mathrm{~g}$. per $100 \mathrm{ml}$. Absorption of oral iron was greatly improved but the barium meal showed very little improvement in the appearance of the duodenum, and mucosal biopsy showed flattened villi and inflammatory infiltrate but no parasites.

He was given gentian violet, grains 1 (66 mg.) t.i.d., in enteric-coated capsules, together with dithiazanine, and the stools were finally cleared of Strongyloides larvae. So far he has remained well.

CASE 4 This 20-year-old man was admitted in March 1965 complaining of swelling of the ankles for the past six months, progressive tiredness for the past four weeks, and nocturnal diarrhoea for three weeks.

On clinical examination he looked much younger than his age being $5 \mathrm{ft} .1$ in. tall and of slender build and juvenile facies, but with normal sexual development. He exhibited all the features of severe malnutrition with a typical dry crazed skin (Fig. 6). He was passing three to four unformed pale, porridge-like stools a day. 


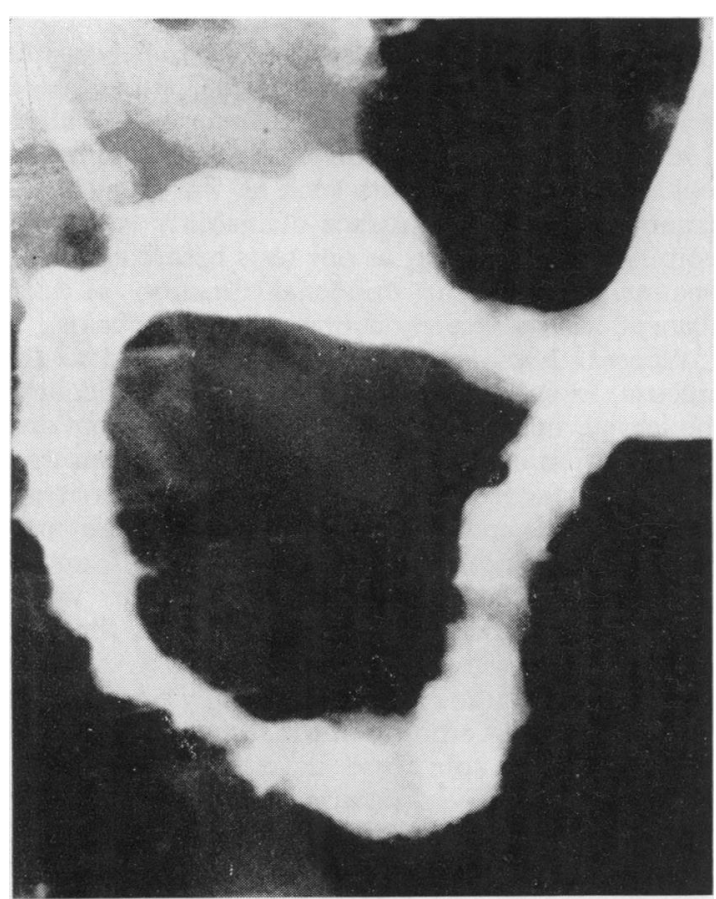

FIG. 7.

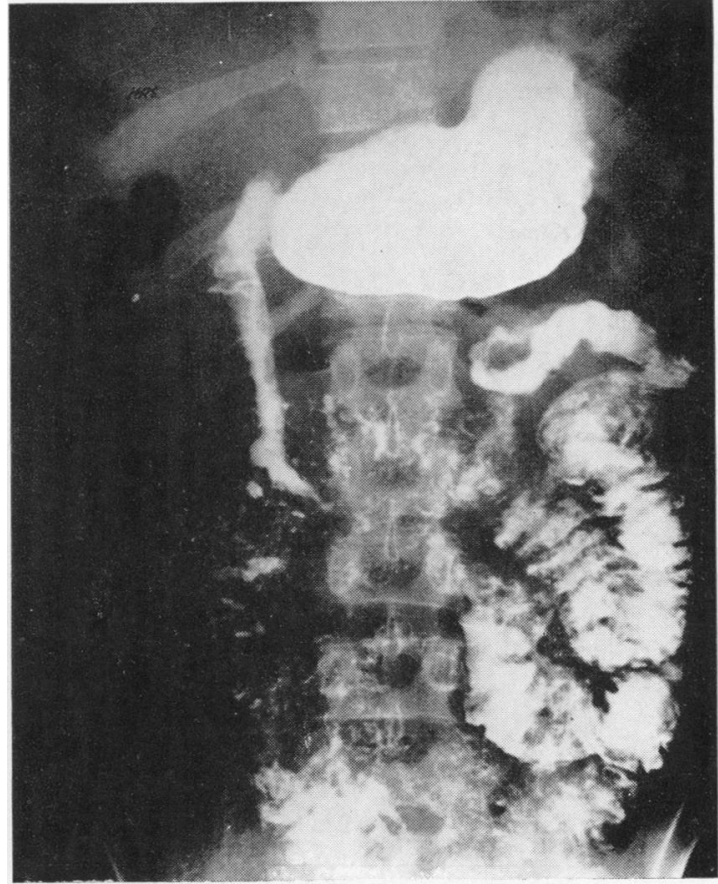

FIG. 8.

FIG. 7. Destruction of mucosa, extensive ulceration, and irregular narrowing of the duodenal loop in case 4.

FIG. 8. Case 4 two and a half hours after barium meal. Note delay in gastric emptying, an obstruction lesion in the third part of the duodenum, ulceration of the proximal jejunum, and dilatation ond oedema of more distal jejunal loops.

Microscopic examination revealed approximately 1,280 S. stercoralis larvae per $\mathrm{ml}$. of packed stools.

He had a moderate iron-deficiency anaemia: $\mathrm{Hb} 9 \cdot 3 \mathrm{~g}$. per 100 ml., M.C.H.C. $29 \%$, and a random serum iron specimen contained $18 \mu \mathrm{g}$. per $100 \mathrm{ml}$. of serum with a total iron-binding capacity of $123 \mu \mathrm{g}$. per $100 \mathrm{ml}$., saturation $14.6 \%$. Serum proteins were $4.0 \mathrm{~g}$. per $100 \mathrm{ml}$., albumin 1.0 g., and globulin $3.0 \mathrm{~g}$. per $100 \mathrm{ml}$.

Absorption tests were grossly abnormal. Xylose excretion was only $10 \%$ of the dose with a peak serum level of $18 \mathrm{mg}$. per $100 \mathrm{ml}$. Iron absorption was flat over four hours and $a^{131} \mathrm{I}$ triolein absorption test showed a maximum absorption at four to six hours of $0.34 \%$ of the dose (normal $15 \%$ ) and $100 \%$ of the dose appeared in the stools over the following $\mathbf{7 2}$ hours (normal less than $2 \%$ ). A glucose tolerance test showed a 'diabetic' curve: fasting, $86 \mathrm{mg}$; one hr., $190 \mathrm{mg}$; two hr. $281 \mathrm{mg}$.; three hr. $300 \mathrm{mg}$.; four hr. $290 \mathrm{mg}$. per $100 \mathrm{ml}$.

Barium meal examination displayed smooth atrophic mucosa in the pyloric antrum with reduced peristalsis. The duodenal loop was aperistaltic, irregularly narrowed with complete absence of mucosal pattern and extensively ulcerated throughout. The narrowing was most marked in the third part of the duodenum where there was again delay in the passage of barium (Fig. 7). A radio- graph taken after two and a half hours demonstrated delay in gastric emptying, the presence of an obstructive lesion in the third part of the duodenum, and ulcerative changes in the proximal jejunal loop similar to those seen in the duodenum. The more distal jejunal loops were dilated and oedematous (Fig. 8).

Peroral biopsy of the duodenal mucosa taken from about the beginning of the third part showed severe infestation with $S$. stercoralis and marked atrophy of villi.

The patient is responding to treatment and the stools are now free of larvae.

\section{DISCUSSION}

Strongyloides stercoralis ova and larvae resemble very closely those of the hookworm. There are several points of difference but these can be easily missed if not specifically looked for. If larvae are found in freshly voided stools, strongyloidiasis, rather than hookworm infestation, should be suspected.

These four cases show that infestation with Strongyloides may produce a duodenitis and 


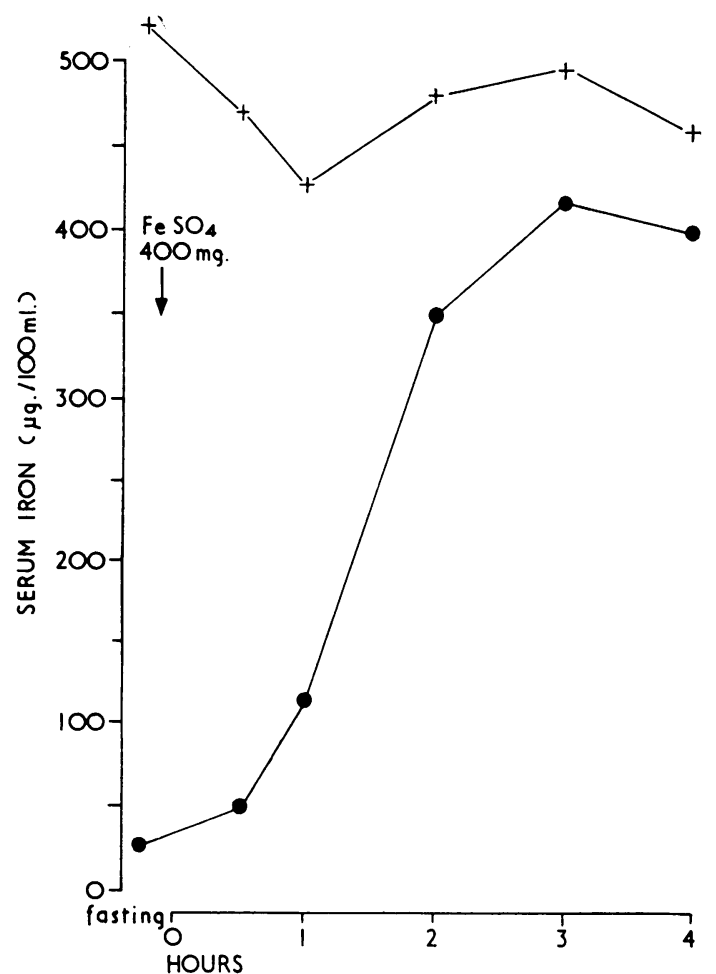

FIG. 9. Iron absorption in a 17-year-old male with untreated hookworm anaemia. In spite of gross iron deficiency the serum iron levels rise steeply:

serum iron, +- + total iron-binding capacity.

jejunitis causing intestinal malabsorption and steatorrhoea. There are conflicting reports as to whether hookworms will do this. Investigators in Puerto Rico, where tropical sprue is common, have reported recently on 14 cases of intestinal malabsorption associated with Necator americanus infestation (Sheehy et al., 1962). Steatorrhoea has also been reported in east Pakistani immigrants to Great Britain infested with Ancylostoma duodenale (Salem and Truelove, 1964). On the other hand, in a large series of cases of hookworm disease reported recently from West Africa (Gilles, Watson, Williams, and Ball, 1964), there was no evidence of malabsorption.

The delayed and impaired rise in the serum iron level following oral iron in these cases is not found in hookworm diseases (Fig. 9), where serum iron values rise sharply after oral iron. The flat serum iron curve before treatment cannot therefore be accounted for on the grounds of an increased rate of utilization of iron. We cannot claim, however, that our patients were unable to absorb iron because it has been shown that iron is absorbed from food along the whole of the small gut and the contribution of the duodenum to iron absorption is indispensable only when a large dose of iron is given (Duthie, 1964). It has been pointed out by Callender and Malpas (1964) that low serum iron levels after unphysiological doses of iron salts such as was used by us cannot be taken as evidence of inability to absorb iron in food. However, as our tests before and after treatment show, the duodenal function of iron absorption was severely depressed in these cases.

Whereas hookworms are merely attached to the mucosa, in strongyloidiasis the worms, particularly the larvae, invade the mucosa causing oedema and inflammation of the duodenal walls. The lesion then leads to a form of stenosis resulting in persistent vomiting and consequent malnutrition. This malnutrition may dominate the clinical picture and is again in contrast to hookworm disease, where malnutrition is rare. In two of these cases the level of serum albumin was extremely low, as was the level of transferrin. This could possibly be the result of anorexia and vomiting but it seems unlikely that this could be the sole cause. Levels as low as this, in the absence of liver disease, are only found in protein-losing states. This suggests that protein is being lost from the inflamed duodenal mucosa in strongyloidiasis. The high mortality in this disease (Bras et al., 1964) can be largely attributed to the severe malnutrition. Although folic acid absorption was depressed in case 1, this was probably not severe enough to cause folic acid deficiency anaemia over a short period of time. Anaemia due to folic acid deficiency is rare in Jamaica, even in pregnancy, because of the high folic acid content of the local diet.

The radiological changes seen on barium meal examination were similar in the first three cases and more advanced in case 4 . They are characteristic enough to arouse suspicion of duodenal infestation with Strongyloides whenever seen. The mucosal oedema, duodenal dilatation, delay in the third part of the loop with abnormal motility, are, however, not specific to this disease. Similar appearances are observed in 'arterio-mesenteric occlusion', inflammatory conditions of the small bowel, biliary and pancreatic disease (Simon and Lerner, 1962), and Durrance (1962) has described a similar lesion in regional enteritis of the duodenum. The severe ulcerative duodenitis of case 4 is a feature which has not been previously recorded.

The duodenal lesion in these cases is reversible, as evidenced by biopsies of the duodenum after successful treatment. Specific therapy with dithiazanine is nearly always effective, although in one of our cases the stools continued to harbour larvae until gentian violet was prescribed as well. Dithiazinine 
treatment is not without hazards, as was shown by case 1 , when profuse diarrhoea and severe potassium depletion forced us temporarily to discontinue treatment.

We are grateful to Dr. K. Wood, Pathology Department, U.W.I., for performing the ${ }^{131}$ I triolein test on case 4; to the nursing staff of the University College Hospital for their cooperation in the investigation of these patients, and to the Clinical Photography Department for the photographs.

\section{REFERENCES}

Alcorn, M. O., and Kotcher, E. (1961). Secondary malabsorption syndrome produced by chronic strongyloidiasis. Sth. med. J. (Bgham, Ala.), 54, 193-197.

Amini, F. (1963). Giardiasis and steatorrhoea. J. trop. Med. Hyg., 66, 190-192.

Beale, R. N., Bostrom, J. O., and Taylor, R. F. (1961). Rapid incremental methods for the determination of serum iron and iron-binding capacity. J. clin. Path., 14, 488-495.

,$--(1962)$. Improved rapid methods for the determination of iron content and binding capacity of serum. Ibid., 15, 156-160.

Bras, G., Richards, R. C., Irvine, R. A., Milner, F. P. A., and Ragbeer, M. M. S. (1964). Infection with Strongyloides stercoralis in Jamaica. Lancet, 2, 1257-1260.

Callender, S. T. E., and Malpas, J. S. (1964). Anaemia and hiatus hernia. Brit. med. J., 1, 1312.
Chanarin, I., Anderson, B. B., and Mollin, D. L. (1958). The absorption of folic acid. Brit. J. Haemat., 4, 156-166.

- and Bennett, M. C. (1962). Absorption of folic acid and Dxylose as tests of small-intestinal function. Brit. med. J., 1, 985-989.

Crosby, W. H., and Kugler, H. W. (1957). Intraluminal biopsy of the small intestine: the intestinal biopsy capcule. Amer. J. dig. Dis., 2, 236-241.

Durrance, F. Y. (1962). Regional enteritis of the duodenum. Amer. J. Roentgenol., 88, 658-661.

Duthie, H. L. (1964). The relative importance of the duodenum in the intestinal absorption of iron. Brit. J. Haemat., 10, 59-68.

Gilles, H. M., Watson Williams, E. J., and Ball, P. A. J. (1964). Hookworm infection and anaemia. Quart. J. Med., 33, 1-24.

Jeffries, G. H., Weser, E., and Sleisenger, M. H. (1964). Malabsorption. Gastroenterology, 46, 434-466.

Roe, J. H., and Rice, E. W. (1948). A photometric method for the determination of free pentoses in animal tissues. J. biol. Chem., 173, 507-512.

Salem, S. N., and Truelove, S. C. (1964). Hookworm Disease in immigrants. Brit. med. J., 1, 1074-1077.

Sheehy, T. W., Meroney, W. H., Cox, R. S., Jr., and Soler, J. E. (1962). Hookworm disease and malabsorption. Gastroenterology, 42, 148-156.

Simon, M., and Lerner, M. A. (1962). Duodenal comparison by the mesenteric root in acute pancreatitis and inflammatory conditions of the bowel. Radiology, 79, 75-81.

Stemmermann, G. N., and Nakasone, N. (1960). Strongyloides stercoralis infestation. Malabsorption defect with reaction to dithiazanine iodide. J. Amer. med. Ass., 174, 1250-1253.

Zamcheck, N., Hoskins, L. C., Winawer, S. J., Broitman, S. A., and Gottlieb, L. S. (1963). Histology and ultrastructure of the parasite and intestinal mucosa in human giardiasis: effects of atabrine therapy. (Abstract). Gastroenterology, 44, 860. 